\title{
ФУНКЦИИ ПРОИЗВОДНЫХ ОТ ФАМИЛИЙ ПОЛИТИЧЕСКИХ И ОБЩЕСТВЕННЫХ ДЕЯТЕЛЕЙ В ПОЛИТИЧЕСКОМ ДИСКУРСЕ
}

\section{FUNCTIONS OF DERIVATIVES FROM THE SURNAMES OF POLITICAL AND PUBLIC FIGURES IN POLITICAL DISCOURSE}

\section{N. Bolgova}

Summary: The article is devoted to the description of the functions of derivatives from the names of political and public figures in political discourse. The work shows that the main functions of derivatives from the names of political and public figures are nominative, evaluative, predicative, referential, discourse-forming, modus, reflexive, pictorialexpressive, appellative, compressive and functions of agonality and categorization. It is proved that these functions are realized, among other things, due to innovative derivational modifications, such as: a wordformation model with the PRO - prefix, with the -MANIA and -POBIA components and the ZA - and ANTI- prefixes. The practical significance of the work lies in the fact that the study of derivatives from surnames in the aspect of the relationship between language, culture and consciousness can be useful for preventing conflicts in the context of communicative perversion.

Keywords: political discourse, functions of proper names, surnames of figures.
Болгова Наталья Сергеевна

Аспирант, Северный (Арктический) федеральный университет имени М.В. Ломоносова, Архангельск natali609@yandex.ru

Аннотация: Статья посвящена описанию функций производных от фамилий политических и общественных деятелей в политическом дискурсе. В работе показано, что основные функции производных от фамилий политических и общественных деятелей - номинативная, оценочная, предикативная, референциальная, дискурсообразующая, модусная, рефлексивная, изобразительно-выразительная, апеллятивная, компрессивная и функции агональности и категоризации. Доказано, что эти функции реализуются в том числе за счет инновационных деривационных модификаций, как-то: словообразовательной модели с префиксом ПР0-, с компонентами -МАНИЯ и -ФОБИЯ и префиксами 3А- и АНТИ-. Практическая значимость работы состоит в том, что исследование производных от фамилий в аспекте взаимосвязи языка, культуры и сознания может оказаться полезным для предотвращения конфликтов в условиях коммуникативной перверсии.

Ключевые слова: политический дискурс, функции имен собственных, фамилии деятелей.

и функционирования не были предметом специального изучения.

Актуальность исследования обусловлена возрастающим вниманием к изучению языковых фактов в аспекте когниции и коммуникации, а также необходимостью обобщения изучения словопроизводства на базе имён собственных с новых позиций. Исследование производных от имён собственных в аспекте активных процессов русского языка последних лет ещё не проводилось в отечественной лингвистике.

Цель работы - рассмотреть функции производных от фамилий политических и общественных деятелей в политическом дискурсе.

Задачи исследования состоят в том, чтобы исследовать когнитивные и языковые механизмы интерпретации производных на базе фамилий политических и общественных деятелей, показать основные функции производных от фамилий политических и общественных деятелей и исследовать, с помощью каких деривационных модификаций эти функции производными выполняются. 


\section{Методология и методы исследования}

Феномен производных от фамилий политических деятелей описывается в работе в русле современной научной парадигмы - когнитивно-дискурсивной. Методами исследования являются дефиниционный и компонентный анализы, концептуальный анализ фамилии и производных слов и дискурс-анализ.

Материал исследования - авторская картотека, содержащая 1200 производных, образованных на базе фамилий политических и общественных деятелей. Производные и непроизводные, но мотивированные фамилиями, номинации выделены нами методом сплошной выборки из СМИ, том числе электронных. Поскольку в работе речь идёт о современных языковых процессах, хронологические рамки исследования ограничиваются двумя последними десятилетиями (2000-2020 гг.). Средой функционирования производных от фамилий политических и общественных деятелей избраны как нейтральные, так и провластные и оппозиционные СМИ с целью повышения объективности выводов.

\section{Результаты исследования}

Объектом обсуждения в политическом дискурсе становятся политическое событие, ситуация, политический или общественный деятель, политическая дискуссия, политическая оценка ситуации, поведения политика и т.п. $[9 ; 14 ; 15]$. Доминирующим концептом в политическом дискурсе является власть.

Смысловая структура политического дискурса представляет собой совокупность смысловых конструктов, смысловых диспозиций и личностных ценностей, обеспечивающих концептуальную организацию дискурса. Основная цель политического дискурса - борьба за власть, её распределение и использование, формирование общественного мнения и его коррекция. Дискурс имеет общественно-политическую тематику. Субъекты политического дискурса - адресант, субъект-референт и адресат опираются на общие культурные ценности, имеющие национальную специфику. Считаем необходимым подчеркнуть, что мы в работе рассматриваем актуальный политический дискурс, отражающий важные для жизни общества события, ситуации, связанные с концептуальной сферой политика.

Основные прагматические установки дискурса: унижение чести, умаление достоинства личности, искажение образа личности, умаление положительных качеств личности, формирование негативного образа, распространение лживых сведений, обвинение в нарушении правовых или нравственных норм, высмеивание, изменение представлений о личности у электората, коллег и т.п.
В связи с вышеназванными прагматическими установками следует назвать интенциональную характеристику дискурса: искажение (частичное или полное) информации. Для реализации коммуникативной установки адресант использует манипулятивные приёмы и речевые тактики разоблачения, развенчания, осуждения, осмеяния, насмешки, иронии и т.п. Осуждению обычно подвергаются коррупция как явление, злоупотребление служебными полномочиями, несоответствие занимаемой должности, а также негуманность, лживость и другие моральные и профессионально-деловые качества личности.

Фамилии и мотивированные ими образования, попадая в политический дискурс, подвергаются процессу вторичной концептуализации. Фамилии начинают под воздействием дискурса концептуализировать новые знания. Н.Н. Болдырев назвал этот процесс «идентифицирующей интерпретацией» [3, с.5-6]. Учитывая специфику семантики фамилий, заметим, что они могут приобрести коннотации, что способствует развитию их значения. При этом какие-то семы могут затушёвываться, а на первый план выдвигаться новые или периферийные.

Основные функции производных от фамилий политических и общественных деятелей (Путин, Ельцин, Навальный, Сталин и др.) связаны с политическим дискурсом. Адресант посредством такого производного называет то или иное явление действительности, вычленяя в нём что-то важное для себя. Поэтому такие производные выполняют номинативную функцию. Производные от фамилий - это особый способ воплощения концептуальных свойств и концептов, проявляющихся в актах познания и оценки мира. Производные от фамилий выполняют оценочную и предикативную функции, так как выражают оценку адресантом политического события, личности политика, ситуации и т. п. Любое оценочное производное выполняет и предикативную функцию. Особенностью исследованных производных является референциальная функция: формирование новых референтов. Это особенно видно, когда производящая фамилия становится символом. В политическом дискурсе при осмыслении производных от фамилий должен учитываться принцип взаимодействия системного значения и функционального осмысления производного в дискурсе. На первый план выдвигается дискурсообразующая функция, которая реализует и дискурсивные стратегии. Особенно важна при этом функция агональности производного, маркирующая дискурс как оппозиционный (путлер, лукашизм, навальдерталец и др.). К дискурсообразующей относим и модусную функцию, демонстрирующую отношение адресанта к референтам производного (ельЦинизм, порохобот, зеленофилы и др.). Сюда же можно отнести и аксиологическую функцию. Аксиология адресанта дискурса определяется выбором словообразовательных средств. Так, имен- 
но адресант использует один из возможных вариантов суффиксации или префиксации, подчёркивая ценностные ориентиры (трамписты, путиноиды, навальнята). Адресант посредством производных от фамилий может выразить метаязыковую рефлексию (рефлексивная функция). Так, называя себя «навариарти», Навальный апеллирует к своей фамилии, обращая внимание на её внутреннюю форму. Приёмы языковой игры актуализируют изобразительно-выразительную функцию производных, маркируя индивидуально-авторскую картину мира (окочуРиться, запутинцы, бандераст). Эту же функцию выполняет приём графиксации (заМАДУРили, ельЦинизм, киллари). К дискурсообразующей функции следует отнести и функцию апеллятивную (ориентация на адресата). Адресант постоянно обращается к ценностным ориентирам носителя лингвокультуры, его сознанию, вызывая «нужные» рефлексии (гитлерасты, зеленоботы, бандерлоги). Дискурсообразующая функция коррелирует с актуализацией дискурсивного значения производных от фамилий. В процессе анализа мы указывали на функцию категоризации производных, которые формируют прототипы категорий, эвокативы, апеллятивы, образцы, характерные примеры и т.п. Поскольку в дискурсе производные от фамилий переходят с языкового кода на дискурсивный, они (или их компоненты) могут подвергаться оценочной перекатегоризации или транспозиции (переход в другой семантический класс). Вот, например, фрагмент дискурса видеоблогера Ивангая: Почему мои видео настолько популярны / Потому что я всегда знаю / что будет популярным в будущем / Я первым снимаю эти видео /Вот так вот я использую свой талант/К примеру / я вангую / что следуюший комментарий будет дебильным [6]. Производной «ванговать» в дискурсе означает «предсказывать» (от имени известной предсказательницы Ванги).

Производные от фамилий содержат социально значимые знания и являются способом интерпретации этих знаний. При этом необходимо учитывать, что особенности их семантической и мотивационной структуры (дискурсивный характер) связаны с компрессивной функцией - доминируют экстралингвистические знания, имплицитного характера.

В политическом дискурсе производные от фамилий входят в систему средств объективации политической реальности и выполняют функцию политической социализации.

Мы относим интерпретацию политического дискурса посредством производных от фамилий к идентифицирующей [3], так как считаем этот процесс вторичной номинацией и вторичной концептуализацией. Фамилия как инструмент идентификации увеличивает в производном свой денотативный потенциал. Производные от фамилий участвуют в формировании концептуального пространства политического дискурса, поэтому стано- вятся фактором познания и оценки мира, структурируя систему репрезентации знаний как языковых, так и экстралингвистических.

Особо следует подчеркнуть участие производных от фамилий в инновационных деривационных процессах. Поэтому некоторые мотивационные модели таких производных формируются непосредственно в дискурсе. Так развивается деривационный потенциал фамилий. Например, среди производных популярным стал префикс АНТИ-: Антитрамповские демонстрации начинаются в США, а избранному президенту помогут байкеры [1]; Господин Антинавальный. Выучили ли вы это имя и фамилию - Александр Бречалов? [5]; За яркость выражений Захарову даже прозвали «Анти-Псаки»; $B$ случае с Каиром нашел свое наглядное проявление свойственный и другим государствам мира феномен «антиКлинтон», то есть подход «кто угодно, только не она» (примеры Л.В. Рацибурской и Е.В. Щениковой [8, с.69]); Если за один день уволить сотни тысяч украинских милиционеров, то не выйдет ли эта армия недовольных на новый, только теперь уже антипорошенковский Майдан? [4] и др. Наблюдается нарушение закона семантического согласования, но префикс АНТИ- усиливает продуктивность, реализуя негативную коннотацию производящей фамилии. Пространственный префикс 3А- тоже стал встречаться в производных от фамилий: По-видимому, запутинские чекисты предполагают сделать из Удальцова нечто вроде краснознамённой пусськи. И начать бесконечную дискуссию, можно ли свергать Путина на иностранные деньги. Ленин же брал у немцев! [12]. Префикс актуализирует пропозиционную ситуацию голосовать ЗА Путина, быть на стороне Путина, быть приверженцем идеологии Путина. Единичными пока являются и префиксоиды ПОЛУ-, ЛЖЕ-: Я не могу защищать полуПутину. Это без меня (т/к «Дождь» интервью с Лией Ахеджаковой, которая считает Марию Бутину, задержанную в США, дочерью Путина) [16]. В основе номинации «лжепутин» лежит установка на поправки в Конституции с целью продления срока президентства. Так называют тех руководителей, которые принимают меры для продления своего срока управления государством. Мотивационным признаком становится отождествление конкретных поступков Путина и кого-либо ещё. Достаточно продуктивной в номинациях от фамилий стала приставка ДЕ-: десоросизация, деельцинизация, дечубайсизация. Префикс актуализирует процесс, противопоставленный тому, что назван в производящем слове.

Особенно хочется подчеркнуть появление словообразовательной модели с префиксом ПРО-: Поведение подсудимого шокировало даже отчётливо пронавальные медиа, многие из которых были вынуждены заменять в онлайнах прямую речь своего лидера фразами «кричат друг на друга» или «начинается перепалка». Навальный уничтожил себя как политика за один день 
[13]; Давайте углубимся в нелёгкое признание простого русского поэта, члена пропутинского Изборского клуба [11]. Как метко заметил Писатель и публицист Юрий Поляков, префикс ПРО- в таких контекстах становится синонимичным префиксу ПОД-, маркирующим сему «подчинения, зависимости». Пока ещё малопродуктивными являются и словообразовательные модели с компонентами -МАНИЯ и -ФОБИЯ: Правда, отечественные бизнесмены страдают особой формой «трампомании» [2]; От обамамании до обамафобии всего один президентский срок (примеры Л.В. Рацибурской [7, с.12]); трампофобия: ведущие американские СМИ не могут смириться с итогами выборов [10].

\section{Выводы}

Таким образом, основные тенденции в процессе функционирования производных на базе фамилий политических и общественных деятелей основаны на идее, что производные от фамилий актуализируют новые смыслоформы как результат когнитивной деятельности носителей лингвокультуры. Эти производные позволяют выделить значимые для русского языкового сознания ценностные ориентиры. Основные функции производных от фамилий политических и общественных деятелей - номинативная, оценочная, предикативная, референциальная, дискурсообразующая, модусная, рефлексивная, изобразительно-выразительная, апеллятивная, компрессивная и функции агональности и категоризации. Эти функции реализуются в том числе за счет инновационных деривационных модификаций, как-то: словообразовательной модели с префиксом ПРО-, с компонентами -МАНИЯ и -ФОБИЯ и префиксами ЗА-и АНТИ-.

\section{ЛИТЕРАТУРА}

1. Антитрамповские демонстрации начинаются в США, а избранному президенту помогут байкеры. Режим доступа: https://www.mk.ru/ politics/2017/01/15/antitrampovskie-demonstracii-nachinayutsya-v-ssha-a-izbrannomu-prezidentu-pomogut-baykery.html (дата 0бращения: 30.09.2021).

2. Антонова Т. Российских бизнесменов накрыла «трампомания»: именем президента США назвали дом быта // Комсомольская правда. 09.11.2016. Режим доступа: https://www.mk.ru/social/2016/11/09/rossiyskikh-biznesmenov-nakryla-trampomaniya-imenem-prezidenta-ssha-nazvali-dom-byta.html (дата 06ращения: 29.09.2021).

3. Болдырев Н.Н., Панасенко Л.А. Когнитивная основа лексических категорий и их интерпретирующий потенциал // Вопросы когнитивной лингвистики. 2013. № 2. C. 5-12.

4. Ганапольский М. Украина Петровской эпохи // Комсомольская правда. 27.05.2014. Режим доступа: https://www.mk.ru/politics/2014/05/27/ukrainapetrovskoy-epohi.html (дата обращения: 29.09.2021).

5. Господин Антинавальный. Режим доступа: https://www.mk.ru/politics/2014/06/22/gospodin-antinavalnyy.html (дата 0бращения: 29.09.2021).

6. Комменты в реальной жизни «5». Үou Тube-канал «Ивангай». Режим доступа: https://www.youtube.com/watch?v=0b-vffySvgw (дата 0бращения: 29.09.2021).

7. Маркова Е.М., Рацибурская Л.В., Иссерс О.С., Мельник Ю.А., Зайцева И.П., Сипко Й., Радченко М.В. Роль СМИ в демократизации и креативизации современного русского языка (круглый стол) // Вестник Московского государственного областного университета (электронный журнал). 2017. № 1. С. 1-51.

8. Рацибурская Л.В., Щеникова Е.В. Словообразовательные средства создания экспрессии в массмедиа и интернет-коммуникации: наименования лиц // Актуальные проблемы стилистики. 2017. № 3. С. 65-77.

9. Сидорова Т.А. Когнитивные механизмы формирования социально-политического дискурса // Когнитивные исследования языка. Вып. 30. Тамбов: ТГУ им. Г.Р. Державина. 2017. С. 628-631.

10. Трампофобия: ведущие американские СМИ не могут смириться с итогами выборов // Режим доступа: https://www.youtube.com/watch?v=rDculXpxxl8 (дата обращения: 29.09.2021)

11. Угланов А. Паника в Изборском клубе // Аргументы недели. Режим доступа: https://argumenti.ru/politics/2020/05/668169 (дата 0бращения: 29.09.2021).

12. Чекистский цирк. Режим доступа: https://pioneer-lj.livejournal.com/1510552.html (дата обращения: 29.09.2021).

13. Шереметьев В. Навальный уничтожил себя как политика за одни день // Проза.Ру. Режим доступа: https://proza.ru/2021/02/20/1085 (дата обращения: 29.09.2021).

14. Amatov A.M., Sedykh A.P., Ivanishcheva 0.N., Sidorova T.A., Bolgova N.S., Zamarina E.V. Ideological American political discourse // Revista Turismo: Estudos \& Práticas. 2020. № 5. Pp. 1-9.

15. Sedykh A.P., Ivanishcheva 0.N., Sidorova T.A., Bolgova N.S., Bolgova E.V. Politician's linguistic personality as key figure of institutional discourse // Revista Inclusiones. 2020. Vol. 7. Pp. 347-358.

16. Армен Гаспарян «Ахеджакова в интервью радио «Свобода»: «Я не могу ее поддержать. Я не уверена, она Бутина или Путина. Я не могу защищать полуПутину. Это без меня»» (https://twitter.com/a_gasparyan/status/1021238072581779457)

(с) Болгова Наталья Сергеевна (natali609@yandex.ru) 